\title{
19ertum \\ CULTURE AND TRADITION OF WINE DRINKING IN POLAND IN THE HALF OF THE SIXTEENTH CENTURY
}

\author{
Anna Odrzywolska-Kidawa \\ Academy of the Jan Dlugosz in Czestochowa, Institute of History, \\ Czestochowa, Poland \\ CMESTE \\ JEL Category: A14, Z13
}

\begin{abstract}
The paper fits in the area of anthropological research on everyday life from a historical perspective. The paper concerns the habits of wine consumption in the Polish lands in the sixteenth century and the range of its uses. The materials used in researching the project included Polish narrative sources - herbaria and chronicles, as well as accounts of foreigners who visited Poland in the studied period. As an imported beverage, wine was expensive and thus treated as a luxury drink. It was drunk mostly by people of high social and material status. The practice of serving wine, instead of locally produced beer, was often criticised by contemporary moralist writers. Wine was associated with foreign cultural influences, and seen as a departure from the traditional beer. In the Polish lands in the sixteenth century, wine was used as a drink, medicine and cooking ingredient. Wine was imported from southern Europe, mostly Hungary, Moravia, Austria, Macedonia, Istria, Italy and Greece. French, Spanish and Rhenish wines were less popular. Sweet wines dominated among the imports. As Poles weren't familiar with the sophisticated taste of premium wines, merchants sometimes adulterated wine by adding various ingredients. Despite vociferous opposition to wine drinking from those who supported traditional Polish ways of drinking, eating, clothing and culture in general, wine gained more and more consumers and its sales steadily grew.
\end{abstract}

Keywords: wine, culture, culinary habits, Poland, sixteenth century

\section{INTRODUCTION}

Wine is rightly associated with southern European countries. In those areas, a climate supportive of viticulture led to a development of a habit of daily wine drinking. Things looked differently in Poland, where the geographical location, weather

Address of the author: Anna Odrzywolska-Kidawa 奉=" a.odrzywolska@wp.pl conditions and other factors determined the scale of wine consumption. Although the tradition of drinking wine in Poland goes back to the Middle Ages, when vineyards were established and wine produced in the southern parts of the country, wine growing ceased due to climate changes and the onset of the so-called Little Ice Age in the middle of the sixteenth century. Because of the disappearance of vineyards from the Polish lands, and as a result of the collapse of the internal market, it became necessary to import wines from abroad (Dias-Lewandowska, 2014 pp. 22-24). 


\section{RESEARCH PROBLEMS AND SOURCES}

The subject of my analysis is the place of wine among other drinks consumed during the Polish Renaissance, during the reign of the last two rulers of the Jagiellonian dynasty: Sigismund I (15061548) and Sigismund Augustus (1548-1572). I will try to show in which social groups wine was appreciated, at which occasions it appeared on the tables, where it was brought from, what types were popular at the time. An important part of my study will focus on determining what the moralists thought about drinking wine, and what arguments they used to support their opinions. A significant aspect of the analysis will focus on determining the health consequences of wine consumption. The source materials will include Polish narrative sources - herbaria and chronicles, as well as accounts of foreigners who visited Poland and spoke about the culinary traditions and the specific features of our country.

\section{DRINKS CONSUMED IN THE POLISH LANDS IN THE SIXTEENTH CENTURY}

The most common and the most frequently consumed beverage in Poland was beer - it was made into soup with breadcrumbs, and added to boiled and stewed dishes. Beer was given to women during pregnancy and after childbirth for strength and sustenance, it was also used to feed children who were no longer breastfed. It served as a daily drink with meals, and as a festive beverage offered to guests at banquets and feasts. The gentry (szlachta) produced beer themselves at their manor farms, while urban residents bought beer produced in local breweries, of which there were many, and which met the demand for this drink. The belief in healthgiving properties of beer meant that it was also used as a medicine, added to enemas and baths.

Another alcoholic beverage, highly regarded among the gentry, was mead (Kromer, 1984, p. 68). Because of the well-developed tradition of bee-keeping in Poland, it was also home-made at the farms. Because of medicinal properties attributed to mead, and bees themselves being bestowed with special esteem, mead was considered to be a noble beverage. It wasn't drunk every day, but only graced the tables during important celebrations. It was more expensive to produce than beer, and its availability was relatively limited.

In this period, obviously, vodka was already known. Its production was becoming increasingly common among the Polish gentry. However, it wasn't until the next century that this particular beverage began to be strongly associated with the Polish cultural landscape. The knowledge of aqua vitae distillation was popularised by the authors of Renaissance herbaria, who published recipes for distilling high-proof alcohol. As the process was not particularly difficult, distillation apparatus started to appear more and more commonly at manor farms. However, in the sixteenth and the early seventeenth century, there was sometimes no distinction made between spirits and wine, and vodka was called vinum crematum i.e. considered to be a type of wine (Potanski, 1950, pp. 17-25; Kuchowicz, 1971, pp. 667-673).

\section{CONSUMERS OF WINE AND ITS PRICE}

How was wine consumed in the Polish lands? A certain pattern can be observed here regarding social groups in which wine dominated on the tables, and the ones satisfied by homely beer. The main recipient of wine in the sixteenth century was the royal court. Wine was also used during celebration of the Mass, hence the regular orders from the church circles. The members of the higher clergy, often educated at Italian universities and familiar with the customs prevailing in other countries, were particularly fond of wine. It was also consumed by wealthy townspeople. But for the gentry and the richer peasants, for whom beer was the main drink, wine was a special occasion only drink. There were several reasons for this.

The costs of importing wine determined its price, which was high and significantly higher than the price of beer produced in local breweries. As it's known from documentary sources, in Krakow, then the capital of the Polish state, a garniec of beer cost 1 grosz in 1567. Krakow garniec (in Latin olla hydra, congius) was a unit of measure. It was equal to about 3,2-3,3 litres. Meanwhile, a garniec of wine cost 14.5 grosz, while as much as 24 grosz was demanded for a garniec of premium (Muscat or Malvasia) wine (Pelc, 1935, pp. 29, 40-41). It should be noted that system of measurement of 
liquids was different for wine and beer. (Szymanski, 2001) Realising the comparative relationship between wine prices relative to beer prices makes it easy to understand why consumers of wine originated almost exclusively from among the well-off people.

Wine became a symbol of one's financial status. Serving wine during feasts - instead of cheaper beer - emphasised the financial position of the host. The cultural significance of wine could be seen when drinking it became forbidden for townspeople. Sumptuary laws clearly define on what occasions and in what quantities townspeople could consume this expensive beverage. The main goal of such regulations was to restrict access to wine for this particular social group (Estreicher, 1898, pp. 121-125).

As the sixteenth century was the period of growth of the Polish economy, the population of the Polish Crown lands grew wealthier. This in turn translated into a growing demand for imported foreign wines. Despite the high price which traders demanded, the number of consumers significantly increased and this upward trend continued in the next century (Starowolski 1859, p. 51).

\section{CIRCUMSTANCES OF WINE CONSUMPTION}

It is difficult to conclusively assess how much wine was consumed in the Polish lands during this period. Documentary sources do not give a full view of this matter, while it is difficult to find a precise answer to this question in the narrative sources. It is known that poorer people bought wine only to celebrate important family events such as a wedding or a christening. However, among the wealthier, wine appeared on tables without a special occasion. The profligate served this expensive drink during feasts they organised or bought it at the inn, at an even greater expense. The clergy, and especially the Church hierarchy, drank wine, not only during the religious rites, but also with their everyday meals.

But overall, there was certainly much less wine drunk in Poland than in the countries of southern Europe. According to the Italian papal nuncio, who visited Poland in 1565, Poles drunk little wine (Ruggieri, 1864, p. 131). Due to its high price, wine was treated as a luxury drink and wasn't indulged in very often.

\section{WINE AS MEDICINE}

Wine drunk in the Polish lands was used not only as a drink served during sumptuous feasts. It is worth noting that it was added as a component of medicinal products, and pharmacies had the privilege of selling wine. Wine was regarded in some circles as medicine, although opinions here were divided. The authors of Renaissance herbariums believed that it could serve as an aphrodisiac. Preparations which included wine among their ingredients were considered beneficial in the treatment of infertility. Wine itself, drunk before labour, had relaxant properties, so it not only accelerated labour and delivery, but also acted as an analgesic. Wine, which, after all, stimulated digestion, was recommended for gastrointestinal problems. Wine in conjunction with cloves and bay leaf was even thought to create a protective barrier against infection with plague (Anonymous, 1899, p. 10). Already at that time there was an awareness that epidemics could spread as a result of drinking dirty water. Therefore, wine or beer seemed to offer a healthier alternative.

It can be assumed that the work of the fourteenth century Italian author Pietro de' Crescenzi (Krescentyn) contributed to the increasing popularity of wine in the Polish lands. In Ruralia commoda... which has been translated into Polish in 1549, book $\mathrm{V}$ was devoted to viticulture, wine production and its use in everyday life. Many indications for therapeutic applications of wine have been included here. Crescenzi recommended wine as a medicine to improve the health of the whole organism. It was supposed to purify the blood and help its circulation, leading to warming of limbs. Thanks to these properties he considered it suitable for drinking by the elderly who had problems with proper blood flow. According to de' Crescenzi, wine should be drunk by everybody who lived in areas with unfavourable climates. He also recommended wine drinking to young people, as it regulated the amount of humours in the body. According to de' Crescenzi, wine was beneficial to the digestive system, especially liver and stomach. He also noticed a positive effect of wine on the mental sphere. Wine 
not only improved mood and induced well-being, but also contributed greatly to stimulating the body to more efficient thinking (Krescentyn, $1549 \mathrm{ff}$. 365-370). Undoubtedly, his opinions about wine contained in the book contributed to the change of beliefs about this drink.

In Poland, not all authors of source materials from the sixteenth century spoke about health benefits resulting from consumption of wine. A particular harm was attributed to drinking wine by children. It was thought to contribute to the development of childhood diseases and to slow down the normal physical development. Children who have been fed wine were thought to be small in stature, with an appearance of a "starved hen" (Rej, 2003, Bk. I, Ch. III, 2, p. 35). A different attitude to the issue of wine consumption by minors than one presented by people living in the countries of southern Europe can be clearly seen here. Sebastian Petrycy of Pilzno knowingly argued that children are fed with wine only in those parts of Europe where there is no access to beer, the latter being far better and healthier in his opinion. $\mathrm{He}$ also argued that serving wine to children may in the future lead to alcohol dependence. What's interesting, he did not have such reservations regarding beer, which according to him, could be drunk by minors with impunity (Petrycy z Pilzna, 1956 , p. 28, 31). Proponents of beer and some authors of herbaria and guides claimed that drinking beer from the earliest years of life made for thriving children of stocky build who are as physically fit as bison (Syrenski, 1613 Bk. IV, f. 948).

There were also more balanced opinions about serving wine to children. The anonymous author of a medical handbook advised giving children small amounts of wine to improve their mood (Anonymous, 1899, p. 10). There was thus no suggestion of dangers in serving wine to children, which is explained by the lack of awareness about the risks resulting from the consumption of alcoholic beverages in the early years of life. Notes on the merits of serving wine to children appeared also in the work on children by Marcin Kwiatkowski, a translation of De ingenuis moribus... by the Italian author Pietro Paolo Vergerio, who lived at the turn of the fourteenth and fifteenth centuries. Although it had to be diluted with water, as was the custom of the
Italians, and served in small quantities, but the writer did not deny the need for giving wine to children. In fact, he believed that wine helped children to digest food and it should be given to them precisely for this purpose. He opposed giving wine to children instead of other drinks (Kwiatkowski, 1889, p. 26). Here, then, the main focus was on the health aspect.

It should be noted that the sixteenth-century writers mostly were not aware that alcohol contained in wine was harmful, especially to children, contributing to the deterioration of their psycho-physical development. Although Mikolaj Rej warned against giving children wine in large quantities and often, but he advised feeding children beer based soups. He did believe, however, that wine weakened the stomach and made one used to delicate dishes. But instead of wine he recommended beer (Rej, Vol. 1, 2003, Bk. I, Ch. III, 2, p. 35). A similar view was expressed by Maciej Wirzbieta (Wirzbieta, 1989, p. 76).

Wine - according to some contemporary Polish moralists - also harmed adults, in whom it led to the so-called inflammation of the body. It had a particularly adverse effect on those with a choleric temperament who, in accordance with the principles of the theory of humours had an excess of yellow bile in the body. On the other hand, those with a sanguine temperament, dominated by blood, could improve their mood by drinking wine (Rej, Vol. 1, 2003, Vol. 1, Bk. II, Ch. VI, 3, p. 224). Even then the effect of drinking wine on the personality of the drinker was observed. Although taking a small amount of wine was thought to contribute to improved mood and well-being, drink to excess, it led to excessive eloquence, overconfidence in decision-making and behaviour (Padrewski, 2003, p. 178; Zbylitowski \& Zbylitowic, 1605, p. 27). It was also pointed out that after ingesting wine women became bolder and more talkative, which wasn't to the liking of all contemporary men (Rej, 1971, Ch.4, Letter 40v, p. 205).

As wine had a had a higher alcohol content than beer, it led to faster intoxication. This is why wine, and not beer, was blamed by the sixteenth-century writers for drunkenness, although they obviously were aware of the fact that drinking large amounts of low-proof alcohol could lead to the same consequences (Wink, 1881, p. 21). 
Wine for medicinal purposes was recommended both internally and externally. It was administered on its own or with the addition of spices or herbs. It was also used for poultices or for rinsing the affected areas of the body. Wine was also added to the contemporary cosmetics, due to a belief in its beneficial effects on the skin.

\section{WINE AS AN INGREDIENT AND SEASONING FOR FOOD}

Sometimes sources mentioned adding wine directly to the food at the preparation stage. It was not a common practice in the described period. The high price of wine definitely discouraged such experiments. Only very wealthy people engaged in such practices. However, they met with disapproval of contemporary moralist writers. Adding wine to stuffing mixtures used to fill in dishes formed in the shape of animals was particularly criticised. Luxury, profligacy, unnecessary extravagance - that's how these attempts at creating very fanciful dishes, both in terms of shape and taste, were judged (Rej, 1971, Ch.2, Letter $14 \mathrm{v}$, p. 101). From another source it is known that wine could be an ingredient of gravy. It also contained seasonings, such as salt, garlic, parsley and, expensive at the time, black pepper (Anonymous, 1899, p. 11). The sources from Gdansk, a wealthy port city, have mentions of adding wine to fish and meat dishes (Klonder, 1989, pp. 119-122).

However, wine didn't feature heavily in the Polish culinary tradition of the period. Even a hundred years later, at the end of the seventeenth century, a cookbook written for a family of the nobility contained a note stating that although you could add wine to food, it would not have a major impact on its taste. Traditionally, seasoning of food with vinegar was much more common (Czerniecki, 2010 , p. 104). However, the aforementioned cookbook also contains recipes for sophisticated dishes (e.g. European Bison loin and Royal-style salmon), for which the chef recommended seasoning with both wine and vinegar, as well as sugar, black pepper and raisins. In this way, a blend of flavours was created, which was intended to be associated with a lavish meal for the most demanding gourmets. The author also suggested adding wine to meat and fish dishes, sauces, mustard, as well as desserts made with almonds
(Czerniecki, 2010, pp. 105-106, 128, 133, 135). It can therefore be seen in how wide a variety of different dishes wine appeared. We must be aware, however, that the recipes included in a cookbook did not necessarily translate to the everyday practice of cookery.

\section{JUDGEMENTS ON WINE BY POLISH MORALIST WRITERS}

More frequent appearance of wine on the Polish tables led to a wave of criticism from contemporary moralists. They complained that wine appeared too often in the Polish reality. They drew attention to the fact that even the lower classes began to serve wine instead of beer, treated as a national drink (Kromer, 1984, p. 66).

The growing popularity of wine also led to the more conservative Poles perceiving it as a cause of cultural changes that occurred in the country. It is worth noting that these changes were noticeable in various areas of life. New food products, more fruit and vegetables in the diet, could be seen. Citrus fruits and other products that had not been present on the tables of Polish nobility and gentry, started to appear. These were purchased mainly from Italy, which, thanks to the marriage of King Sigismund I of the Jagiellonian dynasty to the Italian princess Bona Sforza, began to influence the cuisine and impose new customs. The cultural changes also manifested in clothing. The conservative gentry dressed in the Turkish style, while the more fashionable people incorporated Italian, Spanish and German fashion novelties into their dress. This variety of foreign cultural influences was also apparent in terms of beverages.

In addition to the financial and social status, cultural factors also determined what people drunk. Polish traditionalists drunk beer while those enamoured of the European ideals enjoyed wine. And thus wine started to be associated with alien foreign cultural influences and its drinking was harshly judged by the moralists. Drinking wine, instead of the homely beer, became an expression of attitudes and beliefs. Thus, drinking wine was used not just to show off one's material status but also to express one's adherence to a particular cultural option. It seems that questions of taste were secondary here. 
Another factor determining the choice of a particular beverage was the social origin. As I have mentioned, wine was bought and drunk by wealthy magnates and higher nobility, while lower gentry was content with home-made beer. Pragmatically minded writers warned against entering into marriage with women from wealthy families. Such an unequal marriage was seen as inevitably leading to significant expense. Visits of wealthy wife's relatives were seen as inextricably linked to the necessity of serving wine. This in turn would lead to the financial ruin of a husband of a less wealthy background (Rej, Vol. 1, Bk. II, Ch. I, 2, p. 123).

Wine also appeared in other contexts. While the beer was drunk from wooden vessels, wine required glasses. As glass is a fragile material, the costs of glasses had to be added to the cost of buying wine itself. These were real expenses, especially as the Polish gentry had boisterous habits which included breaking glasses on the heads of fellow participants of feasts (Miaskowski, 1995, p. 343).

Considering all these aspects, it becomes clear that wine became synonymous with a profligate, rakish and extravagant lifestyle leading to squandering of assets (Rej, 2003, Vol. 1, Bk. I, Ch. VI, 1, p. 70). Therefore, the sixteenth century writers often warned against spending fortune on buying large quantities of wine, especially more than could be drunk.

\section{MAIN DIRECTIONS OF WINE IMPORTS}

The gentry, in order to reduce the cost of wine purchase from merchants, sometimes imported wine directly. Some of the imported barrels were then sold, thus covering incurred outlay (Rej, 2003, Vol. 1, Bk. II, Ch. XVI, 9, p. 407).

The directions from which particular types of wine were imported to the Polish lands were determined by several factors. It was necessary to consider issues such as: political relations with specific countries, the distance and the prices demanded by manufacturers and retailers. The taste was less important in the decisions to purchase specific types of wine.

Hungarian wine was by far the most popular and enjoyed enduring fame. Land trade routes along which wine was brought also led to Moravia, Austria, Macedonia, Istria, Italy and Greece. French, Rhenish and Spanish wines were imported by sea. Then, from the port city of Gdansk wine was transported across the country (Ruggieri, 1864, p. 132). In the southern areas of the Polish state wine imported from southern Europe was more frequently drunk, while in the north - the wines brought by sea via Gdansk. The distance that wine had to be transported over, the transport costs and the associated middlemen and broker fees all translated into a high final price.

\section{POPULAR TYPES OF WINE DRUNK IN THE POLISH LANDS IN THE SIXTEENTH CENTURY}

The best known wine consumed in the Polish lands in the described period was the Hungarian Tokay, also called the royal wine (Lewandowska, 2010, p. 35; Lewandowska, 2011, p. 704). In addition to Tokay, a number of other types of wine was present then the Polish market at the time, mostly sweet and/or spiced ones, less frequently dry. The following names appear in the sources: ipokras, trywial, muszkatella, malmazyja, rywula, witpacher, rozeker, piniole, alekanty (Rej, 2006, p. $108,112)$. Ipokras, named in reference to the name of Hippocrates, contained in its composition spices and was used for medicinal purposes. The name of muszkatella probably derived from the Italian word muscatel (Latin muscus), which denotes a species of vine Moscatello, used in southern Italy or Greece for making sweet wine with a musky smell (Bochnakowa, 1984, pp. 8182). Malmazyja (Malvasia, Malmsey) was a red wine produced from a strain called Malvasia in the Peloponnese, Crete, Madeira and the Canary Islands. This well regarded and popular type of wine was imported via the trade route passing through Lviv, which suggests its origins in the Peloponnese or the islands of the Mediterranean Sea. Rywula probably owes its name to the port of Rivoglio, situated on the peninsula of Istria. However, this name also appears in source materials referring to wines imported from France, Italy and Spain. Another hypothesis would be that rywula is the name of the wine produced from the Ribolla strain (Gloger, 1996, p. 192). A problem arises with Witpacher, a name acquired from German, but probably meaning wine imported from Spain, and specifically from the monastery in 
Pajerete (Bochnakowa, 1984, p. 116). In the original version, this wine was called vid pajerete in Spanish. A similar trouble occurs with rozeker, a name only used by the Polish writer and poet Mikolaj Rej. Publishers of the Sixteenth Century Polish Language Dictionary determined that the name should be associated with the Italian word rosichiero, denoting pink-coloured enamel. This wine was to be seasoned with rose oil in order to improve its taste and contribute medicinal qualities (Mrowcewicz, 2012, p. 82). The Polish name piniole probably derives from the Italian word pignuolo, meaning black grapes that were grown in the Milan area. The shape of the bunch of grapes of this variety resembled a pine cone (Italian pigna), and thus the name was applied to the red wine. Alekant (Alikant) probably meant a sweet Spanish wine produced in Alicante, a southeast region of Spain (Bochnakowa, 1984, pp. 34$35)$.

\section{CONCLUSIONS}

As it can be seen, despite the fact that in the sixteenth century Poles treated wine as a foreign, imported drink, and associated it with foreign customs and culture, they knew many types of this beverage. It is worth noting that the names I have discussed originated from source materials of gentry provenance. This shows, on the one hand, a good insight to the wine market. On the other hand, it shows that wine was not an entirely exotic drink, and occasionally appeared on the gentry tables. It also certainly aroused interest among those who, because of low financial status, could not afford to buy it.

It is also worth noting that the Poles were not, after all, sophisticated wine connoisseurs and were not familiar with the taste of outstanding wine varieties. This resulted in fairly frequent cases of wine forgery. The Dutch specialised in wine adulteration, especially of the French wine. They diluted it with cheaper and inferior types of wine or simply water. To improve the taste of wine that'd gone sour, they added a variety of substances including milk, eggs, spices (nutmeg, saffron, ginger, cloves, cinnamon), herbs (liquorice, anise, wormwood), and even gypsum and lime (Klonder, 1989, pp. 31-33). Thus treated wine had a completely changed flavour and significantly lower quality.

It should also be noted that sweet wines predominated among the imports, which gives some idea about the taste preferences of Poles during the described period. In general, few comments about the taste of wine can be found in the analysed source materials. While in the case of beer some understanding can be observed, wine seems to be a drink whose taste qualities were not quite recognized. Wine drinking was more connected to fashion, increasingly popular in the Polish lands. In the period studied, strong antagonisms could be observed between the supporters of drinking wine, and those who advocated consumption of local beer.

It is also worth to conclude this analysis with a mention of attempts to renew the practice of viticulture in the Polish lands which took place during the Renaissance period. Housekeeping guides contained enough detailed advice about soil preparation and planting and grafting vines (Rej, 2003, Vol. 1, Bk. II, Ch. XVI, 2, pp. 393-394). I have also found in a herbarium a recipe for the production of home-made wine from unripe grapes. First, they had to be sun-dried for a few days, then honey was to be added to begin the fermentation and to improve the taste (Spiczynski, 1542, Cap. 260, Letter 96-96v). These trends aimed at ensuring self-sufficiency in wine demonstrate that wine as such began to become an increasingly important, permanent feature of the Polish cultural landscape.

\section{WORKS CITED}

Anonymous, (1899). Dobrego zdrowia rzadzenie, 1532, Pub. and trans. from Latin F. Mymer, Series: Biblioteka Zapomnianych Poetow Polskich XVI-XVIII w., z. 11, Reprint Teodor Wierzbowski, Warszawa: Printing house K. Kowalewski.

Bochnakowa, A. (1984). Terminy kulinarne romanskiego pochodzenia w jezyku polskim do konca XVIII, In: Zeszyty Naukowe Uniwersytetu Jagiellonskiego, Vol. 688, Prace Jezykoznawcze, z. 78. 
Czerniecki S. (2010). Compendium Ferculorum albo zebranie potraw, Eds. J. Dumanowski and M. Spychaj, with a perface by S. Lubomirskiego, $2^{\text {nd }}$ ed. revised, Series: Monumenta Poloniae Culinaria (Polskie Zabytki Kulinarne), Series ed. J. Dumanowski, Vol. 1. Warszawa: Wydawca Muzeum Palac w Wilanowie.

Dias-Lewandowska, D. (2014). Historia kulturowa wina francuskiego w Polsce od polowy XVII wieku do poczatku XIX wieku, Warszawa: Muzeum Palacu Krola Jana III w Wilanowie.

Estreicher, S. (1898). Ustawy przeciwko zbytkowi w dawnym Krakowie, Rocznik Krakowski, Vol. 1.

Falimirz, S. (1534). O ziolach i mocy gich. O Paleniu wodek z ziol. O Oleykoch przyprawianiu. O Rzeczach zamorzkich. O Zwierzetach, o Ptaczech, y o Ribach. O Kamieniu drogim. O Vrinie, O Pulsie, Y o inych znamionach. O Rodzeniu dziatek. O Naucze gwiazdeczney. O stawianiu baniek. Y o puszczaniu krwie. O Rzadzeniu czasu powietrza morowego. O Lekarsztwach doswiadczonych na wiele niemoczy. O Naucze Barwierzkiey, Krakow: Printing house F. Ungler.

Gloger, Z. (1996). Encyklopedia staropolska ilustrowana, wstep J. Krzyzanowski, Vol. 4, $7^{\text {th }}$ edition, Warszawa: Wydawnictwo Wiedza Powszechna.

Klonder, A. (1989). Napoje fermentacyjne w Prusach Krolewskich w XVI-XVII wieku. (Produkcja-Import - Konsumpcja), Series: Studia i Materialy z Historii Kultury Materialnej, Vol. 60, Ed. Zofia Kamienska, Wroclaw: Wydawnictwo Zaklad Narodowy im. Ossolinskich.

Kromer, M. (1984). Polska czyli o polozeniu, ludnosci, obyczajach, urzedach i sprawach publicznych Krolestwa Polskiego ksiegi dwie, 1577. Trans. from Latin S. Kazikowski, Preface and ed. R. Marchwinski, Olsztyn: Wydawnictwo Pojezierze.

Kuchowicz, Z. (1971). Uwagi o konsumpcji produktow destylacji alkoholowej w Polsce w XVI w., Kwartalnik Historii Kultury Materialnej, Year 19, no 4.

Kwapieniowa, M. (1959). Poczatki uprawy winorosli w Polsce, Materialy Archeologiczne, Vol 1.

Kwiatkowski, M. (1889). Ksiazeczki rozkoszne o poczciwem wychowaniu dziatek, 1564, Ed. Z. Celichowski, Series: Biblioteka Pisarzow Polskich, nr 3, Krakow: Wydawca Akademia Umiejetnosci [This work is a translation of the Latin treaty: Vergerio, Pietro Paolo (1472). De ingenuis moribus ac liberalibus studiis. Venice].

Krescentyn, P. (1549). Kxiegi o gospodarstwie, y o opatrzeniu rozmnozenia rozlicznych pozytkow, kazdemu stanowi potrzebne, Transl. A. Glaber, Krakow: Printing house H. Unglerowa.

Lewandowska D. (2010). Historia „kwasnego Francuza”. Ewolucja pojecia dobrego smaku i wyobrazen o winie francuskim w Polsce, In: Rastava Stolicna, Anna Drozdz (Ed.), Historie kuchenne. Rola i znaczenie pozywienia w kulturze, Series: Bibliotheca Ethnologiae Europae Centralis, Series ed. Z. Klodnicki and J. Langer, Vol. II, Cieszyn Katowice-Brno: Wydawnictwo Uniwersytet Slaski.

Lewandowska, D. (2011). Od wegrzyna do szampana: wino, smak i wyroznienie w Polsce XVII-XVIII w., Przeglad Historyczny, vol. 102, z. 4.

Marcin z Urzedowa (1595). Herbarz polski, to jest o przyrodzeniu ziol i drzew rozmaitych. Krakow: Printing house Łazarzowa.

Miaskowski, K. (1995). Zbior rytmow, Pub. A. Nowicka-Jezowa, Warszawa

Modrzewski, A.F. (2003). O poprawie Rzeczypospolitej ksiegi czwore, 1577, Ed. Miroslaw Korolko, Piotrkow Trybunalski: Naukowe Wydawnictwo Piotrkowskie przy Filii Akademii Swietokrzyskiej.

Morawski, Z. (1978). Rozwoj i upadek winiarstwa w Polsce (XII-XVI), Kwartalnik Historii Kultury Materialnej, 26(1). 
Mrowcewicz, K. (Chief ed.), Wilczewska, K., Woronczakowa, L., Nath-Dokurno A. (Vol. eds.), (2012). Slownik polszczyzny XVI wieku, Vol. 36, Warszawa: Wydawnictwo Zaklad Narodowy im. Ossolinskich.

Oczko, W. (1881). Przymiot, 1581, [in:] W. Oczko, Przymiot i Cieplice, Preface by E. Glinka and A. Krynski, Warszawa: Wydawca Towarzystwo Lekarskie Warszawskie.

Pelc, J. (1935). Ceny w Krakowie w. I. 1369-1600, Lwow: Wydawca Sklad Glowny, Kasa im. Rektora J. Malinowskiego; Instytut Popierania Polskiej Tworczosci Naukowej.

Petrycy S. z Pilzna, (1956). Przydatki do Ekonomiki i Polityki Arystotelesowej, 1601, 1605. In: S. Petrycy z Pilzna, Pisma wybrane, Ed. W. Wasik, Preface by K. Grzybowski, Vol. 2, Series: Biblioteka Klasykow Filozofii, Pisarze Polscy, Vol. 20, Krakow: Panstwowe Wydawnictwo Naukowe.

Potanski, J. (1950). Wodka albo gorzalka, 1614, In: Polska satyra mieszczanska. Nowiny sowiźrzalskie, Ed. K. Badecki, Series: Biblioteka Pisarzow Polskich, nr 91, Krakow: Drukarnia Uniwersytetu Jagiellonskiego.

Rej, M. (2006). Krotka rozprawa miedzy trzema osobami panem, wojtem i plebanem, Eds. K. Gorski, W. Taszycki, Wroclaw: Wydawnictwo Zaklad Narodowy im. Ossolinskich.

Rej, M. (1971). Wizerunk wlasny zywota czlowieka poczciwego, Ed. Wladyslaw Kuraszkiewicz, Pt. 1 Phototype and transcription, Wroclaw: Wydawnictwo Zaklad Narodowy im. Ossolinskich.

Rej, M. (2003). Zywot czlowieka poczciwego, 1567/1568, Ed. Julian Krzyzanowski, Vols. 1-2, Wroclaw: Wydawnictwo Zaklad Narodowy im. Ossolinskich; De Agostini Polska.

Ruggieri, F. (1864) Opis Polski, 1565, In: Relacje nuncjuszow apostolskich i innych osob o Polsce od roku 1548 do 1690, Pub. Erazm Rykaczewski, Vol. 1, Berlin-Poznan: B. Behr (E. Bock).

Skarga, P. (2008). Kazanie wtore milosci ku ojczyźnie i o pierwszej Rzeczypospolitej, ktora jest z niezyczliwosci ku ojczyźnie, In: P. Skarga, Kazania sejmowe, Ed. J. Tazbir, with M. Korolko, $7^{\text {th }}$ edition, Wroclaw: Wydawnictwo Zaklad Narodowy im. Ossolinskich.

Skarga, P. (2008). Kazanie osme o szostej chorobie Rzeczypospolitej, ktora jest dla grzechow jawnych i niekarnosci ich, In: P. Skarga, Kazania sejmowe, Ed. J. Tazbir, with M. Korolko, $7^{\text {th }}$ edition, Wroclaw: Wydawnictwo Zaklad Narodowy im. Ossolinskich.

Spiczynski, H. (1542). O ziolach tutecznych i zamorskich i o mocy ich, Krakow: Printing house Wdowa Unglerowa.

Starowolski, Sz. (1859). Reformacja obyczajow polskich wszystkim stanom ojczyzny naszej teraźniejszych czasow zepsowanych bardzo potrzebna, tym zwlaszcza, u ktorych jest biale czarnem, dobre zlem, potega sprawiedliwoscia, wola prawem, upor slusznoscia, krzywda odpustem, niewstyd swiatobliwoscia, utrata pochwala, obzarstwo grzecznoscia, a jednym slowem: Quorum deus venter est, Circa 1650, Pub. K. J. Turowski, Krakow: Wydawnictwo Biblioteki Polskiej.

Syrenski, Sz. (1613). Zielnik Herbarzem z iezyka Łacinskiego zowia To iest Opisanie wlasne imion, ksztaltu, przyrodzenia, skutkow, y mocy Ziol wszelakich Drzew Krzewin y korzenia ich, Kwiatu, Owocow, Sokow Miasg, Zywic y korzenia do potraw zaprawowania Takze Trunkow, Syropow, Wodek Lekiwarzow, Konfektow [...] pilnie zebrane a porzadnie zapisane, Krakow: Printing house B. Skalski.

Szymański, J. (2001). Nauki pomocnicze historii, 5nd ed. revised, Warszawa: Wydawnictwa Naukowe PWN, p. 169. 
Wirzbieta, M. (1989). Gospodarstwo dla mlodych a nowotnych gospodarzow, teraz znowu na ten Nowy Rok poprawione i rozszerzone, 1596, Ed. Jacek Sokolski, Wroclaw: Zaklad Narodowy im. Ossolinskich.

Zbylitowski P. (1605). Schadzka ziemianska. Krakow.

Received for publication: $\quad 22.02 .2016$

Revision received: $\quad$ 24.03.2016

Accepted for publication: $\quad 10.04 .2016$

\section{How to cite this article?}

Style - APA Sixth Edition:

Odrzywolska-Kidawa, A. (2016, July 15). Culture and tradition of wine drinking in Poland in the half of the sixteenth century. (Z. Čekerevac, Ed.) MEST Journal, 4(2), 138-147. doi:10.12709/mest.04.04.02.15

Style - Chicago Sixteenth Edition:

Odrzywolska-Kidawa, Anna. 2016. "Culture and tradition of wine drinking in Poland in the half of the sixteenth century." Edited by Zoran Čekerevac. MEST Journal (MESTE) 4 (2): 138-147. doi:10.12709/mest.04.04.02.15.

Style - GOST Name Sort:

Odrzywolska-Kidawa Anna Culture and tradition of wine drinking in Poland in the half of the sixteenth century [Journal] // MEST Journal / ed. Čekerevac Zoran. - Belgrade : MESTE, July 15, 2016. - 2 : Vol. 4. - pp. 138-147.

Style - Harvard Anglia:

Odrzywolska-Kidawa, A., 2016. Culture and tradition of wine drinking in Poland in the half of the sixteenth century. MEST Journal, 15 July, 4(2), pp. 138-147.

Style - ISO 690 Numerical Reference:

Culture and tradition of wine drinking in Poland in the half of the sixteenth century. OdrzywolskaKidawa, Anna. [ed.] Zoran Čekerevac. 2, Belgrade : MESTE, July 15, 2016, MEST Journal, Vol. 4, pp. 138-147. 